\title{
Higher Education in Nordic Roma and Traveller Policy pÿDocuments Analysing Silences
}

\section{Helakorpi, Jenni}

Bloomsbury Academic

2020

Helakorpi , J \& Isopahkala-Bouret , U 2020 , Higher Education in Nordic Roma and Traveller pÿPolicy Documents Analysing Silences . in L Morley, A Mirga \& N Redzepi (eds), The Roma in European Higher Education : Recasting Identities, Re-Imagining Futures . Bloomsbury Academic , New York , pp. 151-167 . https://doi.org/10.5040/9781350109667.0014

http://hdl.handle.net/10138/326317

https://doi.org/10.5040/9781350109667.0014

unspecified

acceptedVersion

Downloaded from Helda, University of Helsinki institutional repository.

This is an electronic reprint of the original article.

This reprint may differ from the original in pagination and typographic detail.

Please cite the original version. 


\section{Higher Education in Nordic Roma and Traveller Policy Documents - Analysing Silences}

Jenni Helakorpi, University of Helsinki, Finland, and Ulpukka Isopahkala-Bouret, University of Turku, Finland.

\section{Introduction}

The Nordic countries have national Roma and Traveller policies (M SAH 2018; AID 2007; M SAI 2011; NOU 2015; Skr. 2011), which are constituted in the interplay of national and international Roma policy processes and Nordic collaboration (see Helakorpi, Lappalainen \& M ietola 2018). However, in the Nordic countries there are no national statistics based on ethnic or racial identification since the population level statistics are based on register data in which information on ethnic and racial identification is not included. No censuses have been gathered in these countries in decades. Thus, the overall descriptions of the situation of Roma and Travellers are based on estimations and small -scale surveys. However, there are little or no reliable numerical population level estimations. Nevertheless, it is estimated that the completion of basic education and attainment to upper secondary education is distinctively lower in comparison with the rest of the population (Rajala et al 2012; Hagatun in press; NOU 2015; SOU 2010; MSAI 2011). In addition, the current view is that the number of Roma and Travellers participating or having completed higher education (HE) is significantly smaller than the national averages (Alexiadou \& Norberg 2015: 19-20; NOU 2015; Hagatun in press; Rajala \& Blomerus 2015). The social dimension of HE has been firmly expressed in European policy declarations for over a decade. It rests on the idea that students accessing, participating in and completing $\mathrm{HE}$ at all levels should reflect the diversity of populations (London Communique 2007). The main purpose of this social agenda is to make higher education institutions more inclusive and to widen access to the social privileges that higher education offers. 
In this chapter, we analyse how underrepresentation in HE is discussed and problematised in the national Roma and Traveller policy documents in Finland, Sweden, Norway and Denmark. Our approach is poststructural and we analyse the policy documents discursively (Bacchi and Goodwin 2016). We analyse the problem representations and how Roma and Travellers are constructed in the policy texts. Previous research has shown that Roma are often blamed in policy initiatives for their vulnerable social position or the achievement disparities in education (M atache 2017a; Helakorpi et. al 2018; c.f., Gillborn, 2008). Furthermore, multiple studies construct 'Roma culture' as colliding with formal education (Brüggemann 2014). Thus, public discourse address Roma identity as problematic, rather than addressing structural discrimination and racism (Araújo 2016). Against this backdrop, we ask what is silenced and not problematized in the Nordic policy documents. In our analysis, it becomes apparent that through notions of equal opportunity and special support needed by Roma and Travellers, the Nordic policies rely on the framework of multiculturalism instead of anti-racism in education (Troyna 1987; Gillborn 2006).

\section{Roma and Traveller M inorities in the Nordic Counties}

This chapter analyses policy documents that are directed to those Roma and Traveller groups who have national minority status in Finland, Sweden and Norway (M SAH 2018; NOU 2015; AID 2009; Skr. 2011). The Danish Roma do not have a national minority position but from Denmark we analyse the Danish Roma Integration Strategy (M SAI 2011) which the European Union encourages its member countries to develop (European Commission 2011). The history of the Nordic Roma and Travellers, and the policies considering these groups are 
interconnected in multiple ways although differences between and within countries are substantiall $^{1}$ (see e.g. Pulma 2006; M ontesino Parra 2002; Helakorpi forthcoming). Historically, Nordic policies towards Roma and Travellers have been based on assimilation and exclusion; the recent change in the political discourses emphasise human and cultural rights (Pulma 2006).

The current national policy- making and political discourses considering Roma and Travellers have been strongly impacted by international governmental organisations which pay special attention to Roma and Travellers both as a distinctive transnational group, and as national minorities in many European countries (see e.g. Vermeersch 2006; van Baar 2012). Thus, the national policies are impacted by both the internationalisation of minority rights and European Roma inclusion/integration efforts. The EU members Finland, Sweden and Denmark have formulated national Roma Integration Strategies (MSAI 2011; M SAH 2018; Skr. 2011) following the encouragement by the EU (European Commission 2011). Finland, Sweden, and Norway have acknowledged particular Roma and Traveller groups as national minorities and their languages as minority languages according to the Council of Europe's Framework Convention for the Protection of National Minorities (CoE Treaty 157) and the European Charter for Regional or Minority Languages (COE ETS No. 148.). ${ }^{2}$ Historically, Danish deportation legislation and its execution since the $16^{\text {th }}$ century has been fierce (Pulma 2006), which has led to a situation where today Denmark will not grant the national minority status

\footnotetext{
${ }^{1}$ Within the limits of this chapter we are not able to introduce the complex historical trajectories of different Nordic Roma and Traveller groups and the related policies. For an elaborate research about Nordic Roma policies from $16^{\text {th }}$ century to EU, see Pulma 2006 (in Finnish).

${ }^{2}$ Each country define their own national minorities. The groups and group related policies have different historical trajectories. For a comparative research considering the Nordic national minority groups see e.g. edited book by P.A. Krauss and P. Kivistö 2015.
} 
to Roma based on the argument that their presence in Denmark has been discontinuous (see e.g. MSAI 2011). Denmark has been criticised by the European community for not granting Roma national minority status (Lassen Olesen \& Eklund Karlson 2018).

In Finland, the national Roma minority includes one Roma group: Finnish Roma. It is estimated that today approximately 9,000 to 10,000 Finnish Roma live in Finland (Rajala and Blomerus 2015). ${ }^{3}$ The Finnish Roma generally speak Finnish as their mother tongue and the Finnish Romani language is endangered and requires revitalisation measures (Hedman 2015). In Sweden, the national Roma minority covers multiple Roma groups, which are usually categorised by the period of their arrival in Sweden: Travellers (resande), Swedish Roma, Finnish Roma, non-Nordic Roma and recently-arrived Roma generally refugees and asylum seekers from the former Yugoslavia and Kosovo. These groups contain multiple subgroups. According to current estimations there are around 50,000 people who identify as Roma (or Travellers) in Sweden (SOU 2010). Their mother tongue in Sweden varies from different Romani dialects to Swedish, Finnish, and even other languages (Bijvoet \& Fraurud, 2007). In Norway, two different national minority Roma groups have been defined: Roma (Rom) and Travellers (Romanifolk/tatere). It is estimated that there are around 700 Norwegian Roma, and around 4,000 to 10,000 Norwegian Travellers in Norway (Engebrigtsen 2015; M uižnieks 2015). The mother tongue of the Norwegian Roma is usually a dialect of Romani (AID, 2009). Most people identifying as Travellers speak Norwegian as their mother tongue, but the language of Norwegian Travellers (Scandoromani/ Norwegian romani) constitutes an important part of Traveller identity for many (NOU 2015). In Denmark, the estimations vary

\footnotetext{
${ }^{3}$ All the numbers from each of the countries are estimates since there are no statistics based on ethnicity in Nordic countries.
} 
from 2,000 to 10,000 people identifying as Roma (European Commission 2014; Anker, Holch, Høwisch Kristensen and Nielsen 2011). The Roma in Denmark today have varying backgrounds and there is no clear picture of their situation (Busk Laursen \& M uncan 2004; Anker et al 2011; MSAI 2011).

\section{The Nordic Higher Education and Equality of Access}

Finland, Sweden, Norway and Denmark, with populations of 5.5 million, 10 million, 5.25 million, and 5.7 million respectively, have experienced a massive increase in their higher education participation. Participation to higher education has expanded more than tenfold in a half a century (Börjesson, Ahola, Helland \& Thomsen, 2014). In the whole population, the number of young adults (25-34 year olds) with higher education in the Nordic countries is over 40 per cent: in Finland 41.3 per cent, in Denmark 46.6 per cent, in Sweden 47.4 per cent and in Norway 48.3 per cent in 2017 (OECD 2019). The overall inequality in access opportunities has diminished as more students attain higher education (Börjesson, Ahola, Helland \& Thomsen 2014). However, the ongoing underrepresentation of minority groups such as Roma and Travellers indicate inequalities in access.

The Nordic countries share common and globally unique features, such as education largely funded by the state, absence of (or low) tuition fees, and public grants or loans for students (Isopahkala-Bouret et al. 2018). Moreover, by educational law and policy, the opportunity to enter higher education should be as equitable as possible so that every citizen may take full advantage of their educational potential (Isopahkala-Bouret et al. 2018). Egalitarian processes recognise individual talent through meritocratic selection irrespective of class, gender, race or 
ethnicity. Furthermore, there is a political consensus in the Nordic countries that because admissions are egalitarian and financial support for all higher education students exists, there is no need for special initiatives, such as financial assistance/bursaries and affirmative action focusing on minority groups (cf. Thomsen et al. 2013). On further reflection, formal approach to equality, i.e., procedural fairness in access to higher education (Jacobs 2013) is insufficient. It does not recognise how cultural and socio-economic differences create inequalities between individuals. To widen participation to higher education, the playing field must be levelled by creating policy initiatives that remove barriers and compensate children coming from disadvantaged background (Bøyum, 2014; Jacobs 2013). In addition, the social justice approach to widening participation claims that educational structures, systems, and cultures need to transform and turn into more inclusive contexts (Burke 2012).

\section{Methodology and Data}

In this chapter, we analyse how higher education is discussed in the Nordic Roma and Traveller policy documents. We draw from Carol Bacchi's poststructural What's the problem represented to be? approach to policies (WPR) (Bacchi 2009; Bacchi \& Goodwin 2016) where policies are understood as discourses (see also Ball 1993; 2015). Thus, policy documents are perceived as productions of power which shape and enable subjectivities and relations within nation states (Bacchi \& Goodwin 2016; Bacchi 2009; 2000). The ways policies and policy measures are formulated are not understood as simply finding solutions to pre-existing problems but as formulating what is understood as problems. Thus, the policy as discourse approach emphasises how policies enable and constrain 'objects of thought' (see Foucault 
1988: 257). Policies take part in enabling and constraining 'what it is possible for people to become' (Bacchi \& Goodwin 2016: 50).

Our analysis is transnational, analysing the four national policies together and finding discursive tendencies. The policies are entangled with each other due to the long-rooted collaboration between the Nordic countries in the formulation of Roma policies (Pulma 2006) and the internationalisation of minority rights and Roma and Traveller policies as described in the previous section (see also Helakorpi et. al 2018). Our analytical approach is limited to the textual level of policy documents and we do not consider the policy-making practices or implementation of policy. Our data do not permit us to say anything about the interest groups that took part in writing the policy documents, what their agendas were, and what kind of negotiations and compromises they may have had.

We have included in our data the national Roma strategies from Finland, Sweden and Denmark. The Finnish, Swedish and Danish strategies serve as National Roma Integration Strategies (NRIS) following the European Union's coordinated policy process An EU Framework for National Roma Integration Strategies up to 2020. Member states are encouraged to develop, implement, and monitor the NRISs (European Commission, 2011). In Finland, a second national Roma policy, Finland's National Roma Policy (ROM PO) 2018-2022, was formulated in 2018 (M SAH 2018); in Sweden, The Coordinated Long-term Strategy for Roma Inclusion 2012-2032 is from 2011 (Skr. 2011), and in Denmark the national policy Presentation to the European Commission of Denmark's National Roma1 Inclusion Strategy is likewise from 2011 (MSAI 2011). From Norway, which is not a member of the EU and does not 
have an NRIS, we have selected the white paper on national minorities, National M inorities in Norway: About State Policy on Jews, Kvens, Roma, Travellers and Forest Finns (St. M eld 2000), which is the steering policy document concerning Roma and Traveller national minorities. We have also included a local action plan about Roma, the Action Plan for Improvement of the Living Conditions of Roma in Oslo (AID 2009) from $2009^{4}$ and a green paper about Travellers entitled Assimilation and Resistance in Norwegian Policies towards Tater/Romani People from 1850 to the Present (NOU 2015). Thus, the Norwegian policy documents differ from the Finnish, Swedish and Danish ones. Although Denmark has a NRIS, the Danish policy differs from the others since Denmark has not acknowledged Roma as a national minority, which leads to a very different type of approach to Roma issues in Denmark. The Danish Roma strategy mostly refers to the general integration policies of Denmark.

We began the analysis by reading through the Roma and Traveller policy documents and identifying the extracts that focus on HE. After this, we listed all the sections referring to HE and defined the topics in relation to which the Roma and Travellers are discussed. We especially wished to determine whether national policy documents suggested any concrete measures related to widening the participation of Roma and Travellers in higher education. As we found out, HE is a marginalised topic in the Nordic policy documents concerning Roma and Travellers. In the Finnish, Swedish and Norwegian Roma and Traveller policies higher education is scarcely mentioned; in the Danish Roma integration strategy it is not explicitly mentioned at all. Therefore, our research task is characterised as analysing silences in the policy discourse. We analysed the problem representations to which these specific minority

\footnotetext{
${ }^{4}$ The action plan has been evaluated and strongly criticised (Tyldum \& Friberg, 2014), but a new operative policy
} has not been written for the Roma (see also Hagatun in press). 
policies are responding and found out that the presuppositions within these 'problems' discursively position the attainment of Roma and Travellers in higher education as a marginal issue. Furthermore, we identified two problem representations which construct problematic portrayals about Roma: Lack of academic capability and/or aspirations of Roma and Traveller children and Lack of research and teaching about Roma and Traveller culture and language at universities.

\section{Silence about Higher Education of Roma and Travellers}

The Swedish, Norwegian and Danish Roma and Traveller policy documents do not contain any direct measures to promote widening access to higher education. Sally Tomlinson (2008) has described from the British context that when it comes to policies about minoritised racial groups in education, the system "employs the rhetoric of meritocracy and equality of opportunity to disguise a system on increasing inequalities" (Tomlinson 2008: 176). In the next excerpt from the Swedish policy, we observe that the government made a decision not to include a clear goal and measure for higher education participation. They left it out although the Roma delegation suggested it in their green paper on Roma policy:

The Roma delegation proposal: The Delegation proposed the following goals: [...] the same proportion of young Roma people as the national average should study at tertiary level and pass university exams [...] 
Government assessment: [...] All children and school pupils should be given the chance to attain the national targets and develop their knowledge, skills and abilities as far as possible. This applies to the population as a whole, and thus also includes the Roma. [...] (Skr. 2011: 24)

Whereas the delegation proposed a goal which explicitly states that the relative number of Roma studying in higher education should be the same as for the whole Swedish population, the government changed the goal. Thus, there is no specific target for higher education attainment. The Swedish Roma policy relies on the generic discourse of providing pupils with 'the chance to [...] develop their knowledge, skills and abilities as far as possible' (Skr. 2011: 24). In the Danish Roma Inclusion Strategy, the same universalistic target setting is stated as follows:

Goals for active inclusion, education level, employment rate and health in Denmark apply to Roma as well as to other groups with a minority ethnic background in Denmark. The Danish Government holds that equal opportunities are fundamental for the Danish society. (M SAI 2011, 4)

Thus, Danish society, like the other Nordic societies, is based on the ideal of equal opportunities for everyone, which is why no special measures are introduced for minority groups. Further, as higher education is largely funded by the state and degree programmes are tuition-free or low-fee for students, a political consensus exists that there is no need for 
special widening participation initiatives (cf. Thomsen et al. 2013). The discourse conceals the inequalities embedded within the system (Tomlinson 2008; Gillborn 2014).

\section{Problem Representation 1: Lack of Academic Capability and Aspiration}

The policy texts that we have analysed depict problems in basic education and secondary education in a way that constrains academic learner subjectivities for Roma and Travellers. A myriad of research has shown that the expectations set on pupils and students impact on their learning results accordingly and in the case of minoritised students, the expectations tend to be lower (Gillborn 2014). The Nordic ideal of equal opportunity is based on meritocratic selection. It frames access to higher education by constructions of 'capability' that imply that intelligence, potential and ability is innate and detached from social, cultural and educational dis/advantage and inequalities (c.f., Burke et al. 2016; M orley \& Lugg 2009). We find that the analysed policy documents construct Roma and Traveller students as considered to be lacking academic capability and potential. This representation is produced by the measures proposed in basic and upper secondary education and strengthened by the startling silence about higher education in the policies.

Finnish, Swedish and Norwegian policy documents represent Roma and Traveller pupils as in need of special support due to inadequate (learning) skills and lack of family support (Helakorpi, Lappalainen \& M ietola 2018). ${ }^{5}$ Although individual support would no doubt help

\footnotetext{
${ }^{5}$ The new Finnish Roma policy (M SAH 2018) has been introduced after the analysis by Helakorpi et. al. (2018), but the measures considering basic education have not drastically changed.
} 
individual pupils in school, the notion relies on an assumption that the current inequalities in schooling are consequences of Roma specific needs that the school institution has not met. This measure forgets historical injustices and makes Roma pupils the focus of attention instead of the structural issues in schools, such as racism (see Helakorpi 2019). Likewise, the Danish strategy states that 'the schools still find it difficult to integrate the [Roma] pupils into the ordinary classes' (MSAI 2011: 8). The notion of difficulty integrating Roma pupils also represents Roma pupils as inadequate or somehow not fitting in to the school institution (see also Matache 2017a).

The Finnish Roma policy is the only example of introducing an explicit measure to promote the participation of Roma in higher education, namely the establishment of a mentoring programme for Roma higher education students by following examples from Hungary and Portugal (ROM PO 2018: 30). Nevertheless, what is described as the problem in access to higher education is again the lack of (co-)support and study skills of potential Roma higher education students. As the only measure in higher education it also strongly frames the problem to be the support need of Roma and follows the same lines of discourse as the problem representations in basic education - the strict focus on the capabilities of Roma.

The goal of the programmes in question is to support the studies of students with Roma background through peer support and different forms of activities such as courses and education to develop learning abilities. (ROM PO 2018: 85) 
Simultaneously, as Roma and Travellers are represented as lacking adequate academic capability they are also represented in policy documents as lacking motivation and not taking sufficient advantage of their academic potential. This resembles the ways minoritized ethnic groups are typically blamed in public discussions and policies for not being able or willing to integrate (Tomlinson 2008; Araujo 2016). According to the Danish Roma strategy, there is a need for 'a special effort' to 'motivate' bilingual pupils for further education (M SAI 2011: 8). This suggests that the problem in further education is the lack of inner motivation of bilingual individuals rather than problems at the structural level. In the Swedish policy there is also concern about continuing to upper secondary education:

In a labour market that demands higher and higher levels of education, it is crucial for Roma pupils to be challenged and encouraged to move on to upper secondary school and increase their chances of a job. (Skr. 2011: 32)

Just as the Danish policy depicts Roma pupils as in need of motivation, the Swedish policy text describes Roma pupils as in need of challenges and encouragement to attain upper secondary education. In this extract, however, the upper secondary education is anchored to work, leaving out discussion about the eligibility that upper secondary education could give to higher education. This subtly represents a narrower horizon of choices for Roma and yet again detaches Roma from higher education.

As the only Nordic policy, the Finnish Roma policy points out the need to increase participation in the academic track in the upper secondary education. Finnish Roma are underrepresented 
especially in general upper secondary education and the attainment of the matriculation examination, which is the main route to $\mathrm{HE}$. The problem is placed in the attitudes of Roma towards general upper secondary education but also to some extent in guidance practices:

It is necessary to mould the attitudes towards general upper-secondary to be more positive among Roma population. [...] Also in the guidance counselling in basic education, attention needs to be paid to the underrepresentation of Roma students in general upper secondary education and to discussing with Roma pupils about general upper secondary education as an option. (ROM PO 2018, 31)

'Attitude formation', 'increasing motivation', 'challenging' and 'encouraging' all refer to something that needs to change among Roma and Travellers. However, the notion that there is a need to have more guidance encouraging Roma to choose an academic track indicates that current guidance counselling practices possibly steer Roma pupils towards the vocational track and that such discriminatory practice needs to be changed.

\section{Problem Representation 2: Lack of Research and Teaching about Roma Culture and}

\section{Language at Universities}

As described at the outset, in Finland, Sweden and Norway, Roma and Travellers have national minority status and their languages are acknowledged as national minority languages. This creates an interesting tension concerning higher education in the Roma and Traveller policies in these countries since research within universities is emphasised as a way to preserve and 
protect the national minority languages and cultures. This resembles the notions of multicultural education where adding knowledge about minoritised groups is expected in itself to lead to justice while neglecting structural barriers such as racism in the society (Troyna 1987; Helakorpi 2019).

In the Finnish strategy it is suggested that the syllabus in Romani culture and language studies in the university should be expanded. The Finnish strategy also contains a measure about increasing the amount of research on Romani art (ROM PO 2018: 55). In Sweden, the strategy mentions higher education and research in relation to Romani language and national minorities. In the strategy, it is stated that to preserve and develop Romani language there is a need for 'a higher level of training and research' (Skr. 2011: 33). The Norwegian white paper also mentions national minority languages as a subject for research and teaching at Norwegian universities (St. Meld. 2000: 27). This is also discussed in the green paper about Norwegian Travellers (NOU 2015: 84-85).

Sara Ahmed (2000) has written about how 'the Other' enter the epistemological community through knowledge production 'about them' and how their figure as strangers is maintained through knowledge production practices. When it comes to higher education and especially research universities, the Nordic policies produce a tension: the importance of research about the language and culture within the universities is emphasised while the access of Roma and Travellers to universities and knowledge production, i.e. conducting research, is not. Within the Roma studies there have been constant critiques about how those producing knowledge 
about Roma do not identify as Roma themselves and through research practices they often construct Roma as 'the Other' (e.g. Matache 2017b).

\section{Discussion: Silence about HE and Structural Racism}

In this chapter, we have analysed how higher education is discussed in Nordic Roma and Traveller policy documents. We found that there is a discursive silence and a lack of systematic goal- setting related to widening the participation of Roma and Travellers in Nordic HE. Furthermore, we have identified two problem representations from the policies: Lack of academic capability and aspirations of Roma and Travellers, and Lack of research and teaching about Roma culture and language at universities. The policies stem from the multicultural framework in education instead of anti-racism (Troyna 1987; Gillborn 2006). Thus, the policies rely on "support" and adding knowledge about the groups, but they do not address structural problems such as racism in education.

In the policy documents higher education as a topic remains in silence, hence the underrepresentation in HE is not seen as a policy problem that needs specific goals and followup measures. By not making higher education 'an object of thought' (Foucault 1988: 257), the analysed Nordic policy documents limit the horizon of possibilities for Roma and Travellers. Furthermore, the analysed policies totally overlook those Roma and Traveller students who are today entering higher education. However, Roma language and culture are emphasised as important subjects at universities, which results in Roma and Travellers being mostly objects of university teaching and research in the analysed policies. This does not strengthen the 
agency of Roma and Travellers with regard to knowledge production about their own culture and language (or any other research areas).

The silence about higher education is repeatedly constructed through referencing how equal the Nordic education systems already are. These notions reinforce the discourse that everyone in the educational system gets as far as their potential carries them. Through references to universalism and already egalitarian systems, no clear subjectivity within higher education is opened up for Roma and Travellers. The individualistic subjectivity of a pupil who has an opportunity to develop knowledge, skills and abilities as far as possible may not be sufficient to increase the participation in HE. On the contrary, this may put forth the idea that if individuals do not achieve higher education, it is because they did not have the necessary potential. This conceals the structural barriers such as racism (Tomlinson 2008; Gillborn 2014). The subjectivities that are provided for Roma and Travellers by the policy problem representations are as those who are lacking academic potential and having special needs, as needing motivation and attitude change, and if they have aspirations to access and complete higher education, as those who require extra mentoring. Thus, whereas the policies reinforce the notion of everyone getting as far as their potential carries them, implying that the reasons for underrepresentation can be found within the underrepresented groups themselves, the potential and aspirations of Roma and Travellers become questioned in the analysed policy documents. This way Roma and Travellers are constructed as responsible for their underrepresentation in $\mathrm{HE}$ instead of turning the gaze towards structural discrimination and racism (cf. Araujo 2016). 
In this chapter, we have focused on the policy texts and the representations they produce. We have not followed up the implementation of the policies. Although we find that the policy texts are insufficient, in practice such policies have various consequences. For example research and teaching on Romani language in Finland has led to Roma participating in nondegree level language courses. Similarly, in Sweden the non-degree level Roma mediator and mother tongue teacher training are connected to research on Romani language and culture and the students in these training are Roma themselves (Rodell- Olgaç \& Dimitri-Taikon 2016). Thus, strengthening research about Roma and Travellers in the universities have provided possibilities to include Roma and Travellers within higher education communities. We find, however, that it is not enough that the policies may result in some type of participation of Roma and Travellers in HE. Instead, the policies should clearly state a goal to increase participation of Roma and Travellers in student and research communities and the completion of full higher education degrees. The lack of political will to widening participation neglects the important role of higher education for societal transformation.

\section{References}

Ahmed, S. (2000). Strange Encounters: Embodied Others in Post-Coloniality. London \& New York: Routledge.

AID [Arbeids- og inkluderingsdepartementet] (2009), 'Action Plan for Improvement of the Living Conditions of Roma in Oslo'. Oslo: The M inistry for Work and Inclusion. Available online: 
https://www.regjeringen.no/globalassets/upload/fad/vedlegg/sami/nasjmin/handlingsplan_ rom_en.pdf [Accessed 8 April 2019]

Alexiadou, N. \& Norberg, A. (2015), 'Roma, education, and Higher Education policies: The International Context and the Case of Sweden'. Available online: http://umu.divaportal.org/smash/get/diva2:806117/FULLTEXT02.pdf [Accessed 11 July 2019]

Anker, J., Holch, J. A., Høwisch Kristensen, M. and Nielsen, T. A. (2011), 'Denmark. Promoting Social Inclusion of Roma: A Study of National Policies'. European Commission. Available online:

https://ec.europa.eu/social/main.jsp?pager.offset $=0 \&$ catld $=89 \&$ langld=en\&newsld $=1407 \& \mathrm{t}$ ableName=news\&moreDocuments=yes

Araújo, M. 2016. 'A Very “Prudent Integration": White Flight, School Segregation and the Depoliticization of (Anti-)Racism.' Race Ethnicity and Education, 19(2): 300-323.

Bacchi, C. (2009), Analysing Policy: What's the Problem Represented to Be? Frenchs Forest, NSW: Pearson.

Bacchi, C. \& Goodwin, S. (2016), Poststructural Policy Analysis: A Guide to Practice, New York: Palgrave Macmillan. 
Ball, S. J. (1993), 'What Is Policy? Texts, Trajectories and Toolboxes'. Discourse: Studies in the Cultural Politics of Education, 13(2): 10-17.

Ball, S. J. (2015), 'What is Policy? 21 Years Later: Reflections on the Possibilities of Policy Research'. Discourse: Studies in the Cultural Politics of Education, 36(3): 306-313.

Bijvoet, E. \& Fraurud, K. (2007), 'Det romska språket och romsk språkvård i Sverige' Available online:

https:// www.sprakochfolkminnen.se/download/ 18.4aec91b214565240e191055/139868831 2019/Det+romska+sprC3A5ket+och+romsk+sprC3A5kvC3A5rd+i+Sverige+2007.pdf [Accessed 12 April 2019]

Bøyum, S. (2014), 'Fairness in Education - a Normative Analysis of OECD Policy Documents', Journal of Education Policy, 29 (6): 856-870.

Brüggemann, C. (2014) Romani culture and academic success: argument against the belief in a contradiction. Intercultural Education, 25: 439-452.

Burke, P. J. (2012), The Right to Higher Education, Abingdon, New York: Routledge. 
Busk Laursen, J. and M uncan, B. (2004), 'Danmark og romaerne'. romnet.dk. Available online: http://www.romnet.dk/ romafolketdk.html (accessed 11 July 2019)

Börjesson M., Ahola, S., Helland, H. \& Thomsen, J.-P., eds (2014), Enrollment Patterns in Nordic Higher Education, ca 1945 to 2010. Institutions, Types of Education and Fields of Study. Oslo: Nordic Institute for Studies in Innovation, Research and Education (NIFU).

COE [Council of Europe] Treaty 157. (n.d.). Framework Convention for the Protection of National M inorities. Available online: http://www.coe.int/en/web/minorities/text-of-theconvention [Accessed 12 April 2019]

COE [Council of Europe] ETS No. 148. (n.d.). European Charter for Regional or Minority Languages. Available online:

http://www.coe.int/en/web/european-charter-regional-or-minority-languages/text-of-thecharter [Accessed 12 April 2019]

Engebrigtsen, A. I. (2015). 'Educating the Roma: The Struggle for Cultural Autonomy in a Seminomadic Group in Norway', Social Inclusion, 3 (5): 115-125.

European Commission (2014), 'The European Union and Roma - Factsheet Denmark' Available online: https://ec.europa.eu/info/sites/info/files/factsheet_4.pdf [accessed 11 July 2019] 
European Commission (2011), COM M UNICATION FROM THE COM MISSION TO THE

EUROPEAN PARLIAM ENT, THE COUNCIL, THE EUROPEAN ECONOMIC AND SOCIAL

COM M ITTEE AND THE COM M ITTEE OF THE REGIONS An EU Framework for National Roma

Integration Strategies up to 2020. Available online: https:// eur-lex.europa.eu/legal-

content/EN/TXT/?qid=1444910104414\&uri=CELEX:52011DC0173 [Accessed 16 August 2019]

Foucault, M . (1988) 'The Concern for Truth'. In Lawrence D. Kritzman (eds), Foucault:

Politics, Philosophy and Culture. Interviews and Other Writings 1977-1984, 1st ed., 255-270, London: Routledge.

Gillborn, D. (2014), 'Racism as Policy: A Critical Race Analysis of Education Reforms in the United States and England', The Educational Forum, 78(1): 26-41.

Gillborn, D. (2008), Racism and Education: Coincidence or Conspiracy? Abingdon Oxon New York: Routledge.

Gillborn, D. (2006), 'Critical Race Theory and Education: Racism and antiracism in educational theory and praxis', Discourse, 27(1): 11-32.

Hagatun, K, (in press), 'Country Study - The Educational Situation for Roma in Norway', in Studies in International Comparative Educational Science. Focus: Europe. Germany: Springer Verlag. 
Hedman, H. (2015), 'Suomen romanikielen asemaan ja säilymiseen vaikuttavia tekijöitä'. In M. Huhtanen and M. Puukko (eds), Romanikielen asema, opetus ja osaaminen: Romanikielen oppimistulokset perusopetuksen 7.-9. vuosiluokilla 2015, 21-37, Tampere: Kansallinen koulutuksen arviointikeskus.

Helakorpi, J., Lappalainen, S. \& M ietola, R. (2018), 'Equality in the Making? Roma and Traveller M inority Policies and Basic Education in Three Nordic Countries', Scandinavian Journal of Educational Research (ahead of print)

Helakorpi, J. (2019), 'Knowledge about Roma and Travellers in Nordic schools: Paradoxes, constraints and possibilities', in S. Keskinen, U.D. Skaptadóttir \& M. Toivanen (eds), Undoing Homogeneity: M igration, Difference and the Politics of Solidarity, 69-87, Abingdon/New York: Routledge.

Helakorpi, J. (forthcoming), Innocence, Privilege and Responsibility: Power Relations in Policies and Practices on Roma, Travellers and Basic Education in Three Nordic Countries. PhD. University of Helsinki.

Isopahkala-Bouret, U., Börjesson, M ., Beach, D., Haltia, N., Jónasson J. T., Jauhiainen, A., Jauhiainen, A., Kosunen, S., Nori, H. \& Vabø, A. (2018): 'Access and Stratification in Nordic Higher Education. A Review of Cross-Cutting Research Themes and Issues', Education Inquiry, 9(1): 142-154, 
Jacobs, L. A. (2013) 'A Vision of Equal Opportunities in Postsecondary Education', in H-D M eyer, P. E. St. John, M. Chankseliani and L. Uribe (eds), Fairness in Access to Higher Educatino in a Global Perspective, 41-56, Rotterdam: Springer.

Krauss, P.A. and Kivistö, P. (2015) (eds) The Challenge of Minority Integration Politics and Policies in the Nordic Nations. DeGruyter.

Lassen Olesen, C. and Eklund Karlsson, L. (2018), 'Roma Representation in Danish Roma Policy and Public Discourse-A Critical Analysis' Societies, 8 (63).

London Communiqué. (2007). 'Towards the European Higher Education Area: Responding to Challenges in a Globalised World'. Available online:

http://www.ehea.info/Upload/document/ministerial_declarations/2007_London_Communi que_English_588697.pdf (Accessed 10 July 2019).

Matache, M. (2017a), 'Biased Elites, Unfit Policies: Reflections on the Lacunae of Roma Integration Strategies', European Review, 25 (4): 588-607.

M atache, M . (2017b), 'Dear Gadjo (non-Romani) Scholars...' [Blog] Harvardfxb Center for Health and Human Rights. Available at: https://fxb.harvard.edu/2017/06/19/dear-gadjenon-romani-scholars/ [accessed 12th April 2019].

M inistry for Social Affairs and Integration (M SAI), (2011), 'Presentation to the European Commission of Denmark's National Roma Inclusion Strategy'. Available online: 

2019).

M ontesino Parra, N. (2002). Zggenarfrågan: Intervention och romantik. PhD. Lunds Universitet.

M orley, L. \& Lugg, R. (2009), 'M apping M eritocracy: Intersecting Gender, Poverty, and Higher Educational Opportunity Structures', Higher Education Policy, 22: 37-60.

M SAH (M inistry of Social Affairs and Health). (2018). Finland's National Roma Policy (ROM PO) 2018-2022. Helsinki: M inistry of Social Affairs and Health. [online] Available at: http://julkaisut.valtioneuvosto.fi/bitstream/handle/10024/160845/03_18_Suomen\%20roma nipoliittinen\%20ohjelma_2018_2022_web.pdf?sequence=1\&isAllowed=y [Accessed: 20 April 2019].

M uižnieks, N. (2015), 'Report by Nils M uižnieks commissioner for human rights of the Council of Europe following his visit to Norway from 19 to 23 January 2015'. Available online: http://www.

humanrightseurope.org/2016/04/nils-muiznieks-human-rights-annual-report-2015/ [Accessed 9 April 2019].

Norges offentlige utredninger (NOU). (2015), 'Assimilering og motstand Norsk politikk overfor taterne/romanifolket fra 1850 til i dag' (NOU 2015:17). Available online: 
https://www.regjeringen.no/no/dokumenter/nou-2015-7/id2414316/ (accessed 10 July 2019).

OECD (2019), 'Population with tertiary education (indicator)'. doi: 10.1787/0b8f90e9-en (Accessed on 11 July 2019)

Pulma, P. (2006), Suljetut ovet: Pohjoismaiden romanipolitiikka 1500-luvulta EU-aikaan, Helsinki: Suomalaisen Kirjallisuuden Seura.

Rajala, S. \& Blomerus, S. (2015), 'Katsaus aikuisten romanien koulutustaustoihin', Helsinki: Finnish National Agency of Education.

Rajala, S., Salonen, M., Blomerus, S., \& Nissilä, L. (2011). 'Romanioppilaiden perusopetuksen tilannekatsaus 2010-2011 ja toimenpide-ehdotukset'. Helsinki: National Agency of Education.

Rodell Olgaç, C. \& Dimiter-Taikon, A. (2016), Romsk brobyggarutbildning med inriktning mot skolan 2012-2015: Högre utbildning, social mobilitet och interkulturellt kapital. Södertörns högskola.

Skr. 2011. Regeringens skrivelse 2011/12:56 En samordnad och långsiktig strategi för romsk inkludering 2012-2032. Available at: 
https:// www.regeringen.se/49bafe/ contentassets/4a3df6c115584782935d8d9efa7ab6e3/e n-samordnad-och-langsiktig-strategi-for-romsk-inkludering-2012-2032-skr.-20111256 [Accessed: 20 April 2019].

SOU [Statens offentliga utredningar] (2010), 'Romers rätt - en strategi för romer i Sverige. [online] Stockholm'. Available online: http://www.regeringen.se/rattsdokument/statensoffentliga-utredningar/2010/07/sou-201055/ [Accessed 8 April 2019].

St. Meld (2000). St.meld.nr. 15 (2000-2001) Nasjonale minoritetar I Noreg - Om statleg politikk overfor jødar, kvener, rom, romanifolket og skogfinnar. Det Kongelege kommunal- og regionaldepartement. Available at: https://www.regjeringen.no/no/dokumenter/stmeld-nr15-2000-2001-/id585195/ [Accessed 20 April 2019].

Thomsen, J. P., M unk, M. D., Eiberg, M . \& Hansen, G. I. (2013). 'The Educational Strategies of Danish University Students from Professional and Working-Class Backgrounds'. Comparative Education Review, 57(3): 457-480.

Tomlinson, S. (2008). Race and Education: Policy and Politics in Britain, M cGraw-Hill Education. Maidenhead: Open University Press/McGraw-Hill.

Troyna, B. (1987), 'Beyond M ulticulturalism: towards the enactment of anti-racist education in policy, provision and pedagogy', Oxford Review of Education, 13(3): 307-320. 
van Baar, H. (2012), 'Toward a Politics of Representation Beyond Hegemonic Neoliberalism: the European Romani Movement Revisited', Citizenship Studies, 16 (2): 287-296. DOI: $10.1080 / 13621025.2012 .667620$

Vermeersch, P. (2006), The Romani movement: M inority Politics and Ethnic Mobilization in Contemporary Central Europe, New York, NY: Berghahn Books. 